\title{
THE TAX TREATMENT OF FOREIGN WAR LOSSES
}

\author{
Arthur H. Kent*
}

The Revenue Act of I942, from the point of view of revenue yield, is the greatest tax law in our national history. But it is also preeminent in point of the number of important provisions it contains which were motivated by considerations of equity and the prevention of gross hardship to taxpayers. ${ }^{1}$ Some of these, such as the net operating loss and unused excess profits tax credit carry-backs, have the characteristics of basic reforms. It is to be hoped that they will become permanent features of the income tax structure. Section 127 of the Internal Revenue Code, ${ }^{2}$ added by Section I56 of the I942 Act, to which this article is devoted, can hardly claim the distinction of being in itself a basic reform, since it was framed to meet an emergency situation which may not recur. Nevertheless, the fairness and practicality of its approach may afford a helpful precedent in the equitable solution of other unforeseeable problems of the future. Also, the new war loss provisions are sufficiently important in themselves, because of the magnitude of the interests affcted, to warrant some comment, although a complete analysis of the details of the section's application would transcend the space limitations on the present article. Such a comment is not out of place in a symposium devoted to the excess profits tax, for not only is the section, like the tax, a response to the war emergency but also the extremely high rate of tax imposed on excess profits by the 1942 Act was one

* A.B., I917, University of Southern California; J.D., r925, Stanford University. Member of the California Bar, San Francisco. Assistant General Counsel, Treasury Department, I936-1938; Assistant Chief Counsel and later Acting Chief Counsel, Bureau of Internal Revenue, 1934-1936; Professor of Law, University of Chicago, I927-I934. Served as Chairman of Conference of Taxpayers on Foreign War Losses, formed under the auspices of the United States Chamber of Commerce, and presented statements on the war loss problems on behalf of the Conference before the Ways and Means Committee of the House of Representatives and the Finance Committee of the Senate during the hearings on the Revenue Bill of r942. Contributor to legal periodicals.

I Such as the restoration of the privilege of filing consolidated returns for purposes of the normal tax and surtax as well as the excess profits tax, and the numerous remedial amendments to the excess profits tax (subchapter $\mathrm{E}$ of chapter 2 of the Code), including the complete revision of $\$ 722$, relating to excess profits tax relief.

2In addition to $\$ 127$, the following amendments to the Code have important consequences in the treatment of foreign war losses in many cases: $\$ \mathrm{r} 4 \mathrm{r}$, relating to consolidated returns of corporations, particularly the last sentence of $\S_{4} \mathrm{I}(\mathrm{b})$; $\$ 122(\mathrm{~b})$, relating to the two-year carry-back of net operating losses; $\$ 7 \mathrm{ro}(\mathrm{c})(3)$, relating to the two-year carry-back of unused excess profits credit; $\$ 13 I(a)$, eliminating the requirement of election of the foreign tax credit; $\$ 23(\mathrm{k})$, eliminating the requirements of ascertainment of worthlessness and charge-off of bad debts; §II7(j), relating to gains and losses from involuntary conversion; and $\$ 322(b)(5)$, creating a special seven-year period of limitation on claims for refund based on bad debt and worthless security losses. 
of the major factors which made some form of special treatment of these losses imperative, unless gross injustice were to be done.

The text of the provisions of Section $127^{3}$ is quite complicated. But the major principles which underlie it are not. These major principles may be summarized as follows:

(I) The classification of losses falling into the category of foreign war losses should not depend upon the technical form of the foreign property or investment, and such losses, when sustained, should not be subject to the arbitrary limitations imposed upon the deduction of capital losses.

(2) Practical and reasonably definite and certain rules should be provided in the statute for determining in what taxable year such losses shall be deemed to have been sustained for income tax purposes. Otherwise, interminable confusion and much long-drawn out and wasteful litigation would be certain.

(3) Since such practical and definite rules must of necessity be somewhat arbitrary, appropriate provisions should be made to prevent these rules from working gross hardship in certain situations. ${ }^{4}$

(4) Since it is possible that some part of these losses may be recouped by taxpayers in one way or another after the war, specific provision should be made to govern the treatment of such recoupment as income in a manner equitable to both the Government and the taxpayers.

(5) Recognition of stock and security losses should be provided in a limited class of cases where the loss of value is not complete, but where the corporation issuing such stock or securities has sustained war losses which are probably irreparable in character and catastrophic in extent.

It is fair to say that the provisions of Section 127 , which were recommended by the legislative experts of the Treasury, represent an intelligent and bona fide effort to solve the complex problems presented in accordance with these major principles and objectives. Also, the Treasury Regulations, ${ }^{5}$ promulgated under Section ${ }^{2} 27$, are deserving of praise, in the main, as a fair interpretation and application of the new statutory provisions. The factual situations involved in foreign war loss cases, how-

\footnotetext{
${ }^{3}$ Section 127 itself was made applicable to taxable years beginning after Dec. 3I, 1940, but no war loss could be sustained prior to Dec. 7, 194r. Revenue Act of 1942, \$156(b), INT. REv. Code \$127(a)(1). The section occupies nearly four pages in the Code and contains six subsections. Subsection (a) dclimits the cases in which a war loss is deemed to have been sustained and the rules for determining in what taxable year or years such loss may be treated as having been sustained; (b) relates to the determination of the amount of loss on property deemed to be seized or destroyed under subsection (a); (c) relates to the inclusion of recoveries in gross income, i.e., contains the rules governing the tax consequences of recoupment of war losses; (d) contains the rules relating to the basis of recovered property; (e) contains the new concept of deduction of losses attributable to partial worthlessness of investments in property deemed to be destroyed or seized; and ( $f$ ) contains a provision authorizing regulations to determine when and to what extent the deduction of war losses results in a tax benefit.

t The Code provisions relating to carry-back and carry-forward of net operating losses and unuscd excess profits credits, the special rule in $\$ \mathrm{I}_{4} \mathrm{I}(\mathrm{b})$ relating to the carry-over into a consolidated return year of an operating net loss of an affiliate in a prior non-consolidated year, and the climination of the requirement of election of the foreign tax credit, retroactive to I94I taxable years, operate to prevent or minimize such hardships, and were motivated in part or in whole by thesc equitable considerations.

${ }^{5}$ Reg. I03, §.9.127.
} 
ever, are so well nigh infinite in variety and some of them so complex in their ramifications that it is inevitable that the results in some of them may not be wholly satisfactory to all the parties in interest. It may be that experience in administration will establish the necessity of some amendment of Section 127 or modification of a few of the rules which it contains.

Section 127 came into the revenue bill of 1942 in the Senate, being added by the Senate Finance Committee as an amendment, Section 156 , to the House bill. The amendment was quickly accepted, with certain meritorious substantive and clarifying amendments, by the conference committee. The Finance Committee Report stated that the section provided "practical rules for the treatment of property destroyed or seized in the course of military or naval operations during the war, and of property located in enemy countries or in areas which come under the control of the enemy." It also stated that two principal problems are likely to face the taxpayer, the first being to determine when actual destruction or seizure of property occurred in cases in which hostilities in the area of its situs prevent actual determination of the exact date of such destruction or seizure, and the second is to know what facts determine the loss in case the property is located in an enemy-controlled area.

It seems impossible either to deny or to exaggerate the seriousness of both of these problems. The difficulty of obtaining requisite proof of events transpiring in war-torn areas, to say nothing of the exact time of their occurrence, would have been sufficiently great under the most favorable conditions. The problem became insuperable under the conditions of modern warfare, in which the blockade on information from territories invaded and overrun by the enemy was virtually complete. How could American taxpayers with property in Manila or in Malaya determine the fate of such property in point of fact, or the date of its destruction or seizure, if destroyed or seized in fact it was? The burden for calendar-year taxpayers was further aggravated by the fact that the enemy was engaged in the process of overrunning areàs, in which important property holdings and investments were located or centralized, at the very end of the calendar year r94r. Yet the structure of the revenue laws prior to Section 127 , as they related to the allowance of a deduction for losses, assumed the possibility of exact proof both of the fact of loss and the time when it occurred. Finally, the taxpayer's rights in such cases were endangered by a short statute of limitations of three years on claims for refund. No one knew how long the war might last, when the blockade on channels of information would be removed, or whether the requisite proof would still be available when the war was over.

In addition to these uncertainties of fact in cases where there was actual destruction or seizure of property by the enemy, there was grave legal uncertainty as to the status for tax purposes of property which was already under the effective jurisdiction and control of enemy countries upon the dates of the declarations of war after Pearl Harbor or which subsequently came under such jurisdiction and control 
by virtue of enemy occupation of territory. Was actual seizure of such property, or at least the promulgation of a decree by the enemy government authorizing seizure, necessary as a definitive event to establish a loss for tax purposes, or was the mere fact of jurisdiction and control by a nation now become an enemy sufficient? No one short of the Supreme Court of the United States could answer these questions with certainty, and an answer from that tribunal could not be expected for several years. A repetition of the long period of litigation and confusion which enshrouded the administration of the revenue laws in related situations during and after World War I seemed probable, a prospect that could not easily be tolerated. True, the Supreme Court had finally held nearly a decade after that war, in United States v. White Dental Mfg. Co., ${ }^{6}$ that a taxpayer was entitled to a loss deduction in I9I8 on account of property which it was stipulated was actually seized by German authorities in that year, and that the possibility of recovery in kind or of reimbursement after the war was too speculative to postpone realization of the loss. But subsequent to that decision the Chief Counsel of the Bureau, in a belated effort to throw these losses into a year of lower rates, ruled that losses in Germany were sustained in 1917 for the reason that the promulgation of a decree in that year authorizing administrative seizure or sequestration ipso facto constituted a constructive seizure of all American properties in Germany. ${ }^{\text {? }}$

What assurance could there be, in the conditions of r94r, that a realisticallyminded court would not hold that prior control over American property by a totalitarian government plus the fact of a declaration of war was sufficient to constitute a constructive seizure? Certainly such a holding would have done no violence to the realities of the situation. No one could assert seriously, for instance, that the ownership of a factory by an American corporation in Germany or Japan retained any value after the declaration of war in December, 194r.

It is apparent that those who drafted the provisions of Section 127 and the Congress in adopting it took such a realistic view of the situation. " Under Section I27(a) (2), property which is within any country at war with the United States or within an area under the control of any such country on the date war was declared by the United States is deemed to have been destroyed or seized on the date of such declaration. This presumption of destruction or seizure is no prima facie presumption; that it is conclusive is clear from the committee reports and the Treasury regulations. Consequently, mere proof of the presence of such property in an enemy country or an enemy-controlled area at the designated date is ordinarily sufficient to establish a loss. Under Section 127 (a)(I), property situated in an area which comes under control of an enemy country after the date of the declaration of war therewith is likewise conclusively deemed to have been seized or destroyed on the date such control is established.

This statutory rule that property under the control of an enemy country shall e 274 U. S. 398 (I927). ${ }^{7}$ G.C.M. то630, XI-2CB, 97. 
be deemed to have been seized or destroyed on the date of the declaration of war or on the subsequent date when such control is established is not limited in its application to real property or tangible personal property having a physical situs in enemy-controlled territory. It applies also under Section $127(a)$ (3) to numerous types of intangible interests, such as stock, bonds, and the like, which are referable to, and derive their value from, such destroyed or seized property. Suppose, for instance, that a domestic corporation owns stock and bonds of a Dutch corporation all of whose assets were situated in Holland. Since all of such assets are deemed to have been destroyed or seized on the date war was declared against Germany, the stock and bonds in question are likewise considered to have been destroyed or sized, and the loss sustained on that account is to be treated as a loss due to destruction or seizure. It is further specifically provided that Sections $23(\mathrm{~g})(2)$ and $23(\mathrm{k})(2)$ shall not apply to any interest deemed to have been destroyed or seized under Section $127(a)(3)$. In other words, the deduction of such security losses is freed from the capital loss limitations imposed by those sections.

It should be noted, however, that Section I27(a)(3) is limited in its application ${ }^{8}$ to cases in which the interest would have become worthless if the property to which such interest relates had been destroyed. Consequently, if in the above illustration the Dutch corporation had property in England or the United States or in other territory not under enemy control, which would mean that its securities still had some residuum of value, Section $\operatorname{I27}$ (a) (3) would not apply, and no war loss deduction would be allowed on account of such interest unless the case were one in which the conditions of Section 127 (e) could be satisfied. Except for this limitation, however, the section is very broad in its application, and applies equally to land, interests in real property, and to tangible and intangible personal property interests. ${ }^{9}$

\footnotetext{
${ }^{8}$ There is one limited exception to this rule. Section $127(a)(3)$ provides that a taxpayer which owns $100 \%$ (excluding qualifying shares) of each class of stock of a corporation may elect, under Treasury regulations, to determine the worthlessness of its interest, described in such section, in or with respect to the property of such corporation, without regard to the amount of the property of such corporation which would be excluded in determining the adjusted basis of all the assets of the corporation for the purposes of subsection (e), but such amount shall be treated under subsection (b)( $x$ ) as a recovery by the taxpayer in the taxable year with respect to such interest.

The operation of this exception may be illustrated by an example. Corporation $X$, a domestic corporation, owned all the stock of corporation $Y$, having an adjusted basis of $\$ 1,000,000, Y$ being engaged in the extraction and refining of petroleum in Sumatra. All of the assets of $Y$ consisted of land, leases, wells, pipe lines, and refineries in Sumatra, except that $Y$ had bank accounts in New York and London banks aggregating $\$ 100,000$. The properties of $Y$ in Sumatra were intact on January $x, 1942$, but were overrun early in that year by Japanese forces invading Sumatra, and a portion of the plant was destroyed by scorched-earth operations just prior to the invasion. $X$ has a deductible loss on its 1942 return of $\$ I, 000,000$, but must treat the bank accounts of $\$ 100,000$ as a recovery in 1942, resulting in a net war loss deduction of $\$ 900,000$.

The effect of this exception is to carve a small group of cases in which relief would otherwise have to be sought under $\S 127$ (e) out of the latter section and to treat them as cases of total worthlessness under $\$ 127(a)(3)$, with an offset of the value of the assets excluded in the adjusted basis determination prescribed by $\S_{127}(\mathrm{e})$. The principal practical result is to obviate the necessity of liquidation of the subsidiary which is a condition to claiming the benefits of $\$$ I27 $_{(\mathrm{e})}$.

- The Conference Report, Statement of the Managers on the Part of the House, at p. 48, states specifically that, for the purposes of $\$ 127(a)(3)$, land seized in the course of military or naval operations or within an area under enemy control is treated, for the purposes of determining whether the stock
} 
It should not be inferred from the foregoing discussion, however, that war losses referable to the ownership of corporate stock, bonds, or other obligations must in all cases be established, if at all, under Sections I27(a)(3) or I27(e). Such is not the case, for in many instances Section $\operatorname{I27}(\mathrm{a})(2)$ will apply. A typical case to illustrate is one in which a taxpayer owned a minority stock interest or bonds of a corporation incorporated under the laws of Germany, which had a factory in the Reich on December ro, 194x, but which also had substantial bank accounts in Switzerland and perhaps accounts receivable owing by solvent debtors in countries not at war with the United States or even in the United States itself. Section I27(a) (3) would not necessarily apply to such a case, since the destruction of the properties in Germany would not of necessity destroy completely the value of the stock or bonds. The taxpayer cannot satisfy the conditions to relief under Section I27(e). Nevertheless, such a taxpayer will in all probability be entitled to claim a loss on account of this investment under Section $127(a)(2){ }^{10}$ The basis of such application is the fact that the corporation is a German corporation; hence the Nazi government has the power to make an effective seizure of the stock or the bonds of its corporate creature owned by an American taxpayer. Such would not be the case if the corporation in question were one incorporated under the laws of Holland, where only a portion of the corporate properties had come under effective enemy control.11

The problem of timing of war losses with respect to their assignment to the correct taxable year is simple in those cases in which the loss is governed by Section I27(a) (2), as well as in those cases in which a loss claimed under Section $\mathrm{I}_{27}$ (a) (3) represents an interest referable to property deemed to be seized or destroyed, where the property in question is so considered as seized or destroyed under Section I27(a) (2). By the fiat of the statute, such losses must be deducted, if at all, in the taxpayers return for the taxable year in which war was declared against the country in which the property was situated or which had control of the property upon the date of such declaration. This statutory rule may seem arbitrary, but it does have the great merit of definiteness and certainty. Moreover, it can be criticised as arbitrary only upon the questionable assumption that the rule adopted is not the same as that which the courts would have finally declared under the pre-existing law.

or bonds of the corporation owning such land have become worthless, as having been destroyed, even though land may ordinarily be regarded as indestructible.

${ }^{10}$ See Reg. 103, $\$ 19.127$ (a) -3 , for a clear recognition of this principle. The vital issue is whether the enemy country may legally divest the taxpayer of its right to such intangible property in such manner that all other jurisdictions having control of any of the obligations and assets from which such intangible property derives its value would not recognize the taxpayer as having any interest in such obligations and assets. The regulation states: "Ordinarily, if the right of the taxpayer to the intangible property exists by reason of the law and authority of the enemy country, section 127 (a)(2) applies to such intangible property." This would be true ordinarily in the case of stock or bonds or debts of a corporation incorporated under the laws of an enemy country and owned by an American taxpayer. On this sound interpretation, the regulation also specifically recognizes that all public bonds of a country at war with the United States are considered to be within the provisions of $\$ 127(a)(2)$.

${ }^{12}$ See Reg. I03, §19.127(a) -3 . 
It is only in those cases to which Section I27(a)(I) is either applicable directly, or is applicable indirectly through Section $\mathrm{I2}$ (a) (3), that the special rules contained in Section I27(a)(I) may be resorted to. These are all cases in which the taxpayer's property (or investment) was situated in territory which was under control of the United States or a friendly power on the date war was declared against an enemy country, but which was subsequently invaded and overrun by such enemy power. The Far East (Philippines, Hongkong, Malaya, Burma, Singapore, Dutch East Indies, South Pacific Islands, etc.) contains the territories to which the special rules relative to the timing of losses have their chief application. Even here the basic rule applied is that the loss shall be assigned to the taxable year of the taxpayer in which the enemy established its control over the territory in which the taxpayer's property (or investment) was situated.

It is clear that many of these areas, such as Java, Burma, and probably Sumatra, were not invaded in 194r, although danger of invasion was apparent and air raids by the Japanese may have occurred, but remained under friendly control until some time after the beginning of 1942 . The war losses in such territories are clearly I942 losses, at least for calendar-year taxpayers. Likewise, certain islands such as Guam had been completely conquered by Japan before January I, I942. Losses there would be clearly assignable to 1941. It may be there are some instances where particular properties in the former territories were destroyed or seriously damaged by Japanese bombs or scorched-earth operations in December, I94I. Such losses might, of course, be taken in the returns for I94I if the requisite proof is available. There were certain areas, however, such as Malaya, Hongkong, and several of the major islands of the Philippines, where invasion was actively under way at the end of I94I but was not completed until some time early in the following year. About all that can be said is that on December 7 , I94I, the property was in territory then under American or friendly control and that not later than some date in 1942 such control had definitely passed to the enemy. The exact date on which control may be said to have shifted to enemy hands cannot be ascertained.

In cases of this type, Subsection 127 (a) (I) vests in the taxpayer a limited right of election, the manner of exercise of which may determine whether the loss is deducted in the $194 \mathrm{I}$ or 1942 return. If thrown into I94I, an amended return and a claim for refund would usually be necessary. The subsection does this by providing that the taxpayer may choose as the date of destruction or seizure any date which falls between the latest date, as established to the satisfaction of the Commissioner, on which the area wherein the property was situated was under the control of a country not at war with the United States and the earliest date, as so established, on which such area was under the control of an enemy country. If the earlier date falls in I94I and the later date in 1942, the taxpayer's election applies.

It is obvious, however, from the language of the section that the Commissioner's determination as to the dates of loss and acquisition of control will carry great 
weight. Furthermore, the importance of the election will depend to a considerable extent upon the manner in which the statutory term "area" is interpreted in the administrative application of the statute. Too strict and rigid interpretation would virtually destroy the practical value and flexibility of the statutory formula. The regulations indicate a reasonably liberal and practical interpretation will be adopted. Thus, the island of Luzon is specifically recognized as one theatre of military operations and therefore presumably one area, as to which complete American control ceased in December, I94I, and complete Japanese control was not established until the fall of Corregidor in May, I942. The regulations indicate that the entire Philippine group may be treated in like manner. It may reasonably be expected that the Malayan peninsula will be similarly regarded as one area, although the inclusion of Singapore Island in that area may present a more doubtful question. .

Section 127 thus greatly simplifies the administration for tax purposes of foreign war losses by treating property and interests referable to property situated in an enemy country or enemy-controlled territory on the date of the declaration of war as destroyed or seized on that date, and by treating property subsequently coming into enemy control as seized or destroyed at the time such control is established, without regard to whether seizure or destruction in fact is proved. But this method of treatment has even more important substantive tax consequences by reason of its effect upon the classification of these losses. Losses due to destruction or seizure are classified as casualty losses. ${ }^{12}$ As such, they either come into the category or have the substantial effect of ordinary losses and are thereby freed in all cases, without regard to the technical form of the taxpayer's foreign property or investment, from capital loss limitations. ${ }^{13}$ Hence, such war losses may be applied against ordinary business income for excess profits tax as well as normal and surtax purposes, and, to the extent that they arise out of the taxpayer's trade or business, ${ }^{14}$ they will be taken into account in the computation of net operating loss for the purposes of both the new carry-back and the older carry-over provided by Section r22 of the Code.

${ }^{12}$ Reg. I03, \$I9.127(b). Section 19.127 (a) properly interprets the term "military or naval operations" in $\$ \mathrm{I}^{2} 7(\mathrm{a})(\mathrm{I})$ as intended to cover all actions incident to belligerent activities, whether in furtherance of or opposition thereto, and hence as including operations in execution of a scorched-earth policy or rendering a position under threat of attack or other danger more secure or less desirable to the attacker.

${ }^{13}$ In the interests of complete accuracy, it should be noted that, for the taxable years beginning after Dec. 3I, I94I, war losses, which are by statutory fiat treated as due to destruction or scizure, are assimilated into the category of losses from involuntary conversion subject to the provisions of $\delta 117(j)$ of the Code. In most cases this special classification will make no great difference, since all that it means is that such losses must first be offset against gains in the $\$ 117(j)$ category, i.e., gains from involuntary conversion of capital assets held for more than six months or of property used in a trade or business, and gains from the sale or exchange of property used in a trade or business. Any cxcess of losses over gains in the new category will continue to enjoy the status of ordinary losses for tax purposes; only a net gain would be subject to capital gain tax limitations. In taxable years beginning prior to Jan. $x$, 1942, war losses are treated as ordinary losses without even the foregoing technical limitation.

14 This is of practical consequence only to individuals, since all losses of corporations are deemed to arise out of the corporate business and hence will enter into the computation of net operating loss unless excluded by reason of classification as capital losses and the limitations incident thereto. Some individuals may get a lesser tax benefit than corporations out of war losses because of the limitations in $\$ 122$, but their situation in this respect is not worsened by $\$ 127$. 
The foregoing is the most important substantive liberalization made by Section I27. Under the pre-existing law, it is clear that losses due to stock and bond investments becoming worthless by reason of the seizure or destruction of underlying assets would have been subject to capital loss limitations. ${ }^{15}$ As such, they could not have been deducted for excess profits tax purposes nor would they have been eligible to the benefits of Section $122 .{ }^{16}$ Even the classification of losses due to expropriation or sequestration by an Axis government of stock or bonds issued by a corporation incorporated under its laws and owned by American nationals was a matter of serious doubt. ${ }^{17}$ Only in the case of loss of tangible property or of intangibles, other than corporate stocks and securities, directly owned by American taxpayers, by reason of action by enemy governments, could it have been confidently asserted that the loss would have constituted an ordinary loss prior to the enactment of Section 127 .

But for the adoption of certain other provisions in the Revenue Act of 1942 which correlate very well with Section 127 , the more or less arbitrary rules governing the timing of war losses might have produced serious hardship and inequity in certain cases. These other provisions, however, tend substantially to prevent or ameliorate such hardships. The most important of these provisions are the new two-year carry-backs of net operating loss and unused excess profits credit. There are at least a few cases in which American corporations operating directly or through subsidiaries in Sumatra, Java, Borneo, or elsewhere in the Far East lost all their income-producing properties as the result of the Japanese conquest of those areas. Some of these corporations had very substantial taxable incomes for the calendar year x94x, but had little or no income or substantial losses for 1942 and in all probability will have no income for several years thereafter. The formula contained in Section 127 (a) (I) would almost certainly fix their losses for tax purposes in I942. Without the carry-back, a serious hardship would be inflicted in such cases. The new carry-backs of net operating loss and unused excess profits credit to I94I taxable years will provide substantial relief.

One other special situation arose out of the fact that consolidated returns were allowed only for excess profits tax purposes for taxable years beginning prior to January I, I942. In some cases, the foreign properties or investments of affliated groups were concentrated in the ownership of only one or two affliates in a group. If heavy war losses under Section I27 were sustained in a 194r taxable year on account of such properties and investments, the group could get an excess profits tax benefit, if its income were sufficiently large, for all of such losses, but the losses

\footnotetext{
${ }^{16}$ INT. REv. CODE, $\$ \$ 23(g)(2)$ and $23(k)(2)$. It has been pointed out that these provisions are specifically made inapplicable to investment losses under $\$ 127$. See $\$ 127(a)(3)$.

${ }^{10}$ The situation would have been still more serious for taxable years beginning after Dec. 3r, 194r, by virtue of the new provision in $\S_{I I 7}(d)$ of the Code limiting the deduction of corporate capital losses to the amount of corporate capital gains, despite the five-year capital loss carry-over provided by $\$$ II $7(\mathrm{e})$.

${ }^{17}$ But see Emil Stern (1926), 5 B.T.A. 89. Cf. Helvering v. Wm. Flaccus Oak Leather Co. 313 U. S. 247 (I $94 \mathrm{I}$ ).
} 
could be applied for normal tax and surtax purposes only against income of the particular corporate entity or entities in the group sustaining such losses. The result of such application might be a large net operating loss to the particular affiliate or affiliates.

In the event a consolidated return were filed by the group for the I942 taxable year, the rule under the prior law and regulations was that the particular affiliate could carry forward such net operating loss for I94r into 1942 or 1943 only in an amount not in excess of its net income for such year or years. Section I4I(b) of the Code, as amended by Section 159 (a) of the 1942 Act, prevents this harsh result by the following specific provision: ${ }^{18}$

Such regulations shall prescribe the amount of the net operating loss deduction of each member of the group which is attributable to a deduction allowed for a taxable year beginning in r $94 \mathrm{I}$ on account of property considered as destroyed or seized under Section r27 (relating to war losses), and the allowance of the amount so prescribed as a deduction in computing the net income of the group shall not be limited by the amount of the net income of such member.

It is unnecessary to state that, where such I94r war losses have been applied in a consolidated excess profits tax return for a $194 \mathrm{x}$ taxable year to reduce consolidated excess profits net income, the above special provision in Section I42(b) will not operate to allow the group or the particular affiliate a duplicate consolidated excess profits tax benefit in 1942. The special provision relates only to the net operating loss, not the unused excess profits credit, and the carry-over in such a case would be limited in its application to consolidated normal tax and surtax net income. If the group, however, showed a consolidated excess profits income for 194I which was less than its credit by reason of the deduction of war losses, the unused consolidated excess profits credit could be carried forward to reduce consolidated excess profits net income for the subsequent year. ${ }^{10}$

Section 127 has no application in determining whether war losses are to be attributed to sources within or without the United States. That question is left to be determined under Section IIg of the Code. In most cases, at least, such losses would probably be allocable to sources outside the United States. The result is that in the application of the foreign tax credit provided by Section 13I, such losses would be allocated against foreign income and would reduce pro tanto the numerator of the fraction used in the computation of the credit. In cases in which Section 127 operated to throw large war losses into I94r, the effect might be greatly to reduce or even to eliminate the credit for foreign taxes for that year to which the taxpayer would have otherwise been entitled. Many taxpayers had filed their r94r returns and elected the credit under Section I3I, thereby precluding the use of such foreign

\footnotetext{
${ }^{18}$ See Reg. 104, \$23.3r(d)(4), which gives administrative effect to this legislative mandate. Under this regulation the portions of the net operating loss attributed to war losses is the excess of the net operating loss for such year over the amount of any net operating loss computed without regard to war losses. This is both the simplest rule to administer and the most liberal to the taxpayer.

${ }^{10}$ See Reg. 110, \$33.3I(a)(33).
} 
taxes as deductions, before the enactment of the 1942 Act and before the statutory changes relative to war losses were known. Such taxpayers might have been caught in a trap because election of the credit in the return was formerly irrevocable under the statute. The possibility of any such hardship or inequity was prevented, however, by the amendment made to Section I3I (a) eliminating the irrevocable election retroactive to taxable years beginning after December 3I, I940.

The amendment to Section $23(\mathrm{k})$ eliminating the requirements of ascertainment and charge-off in the case of bad debts and thereby making the rule the same for debts as for stocks, viz., the year of worthlessness in fact, will apply to debts, including corporate securities, which might otherwise be war losses under Section I2r, in one important respect. Since this amendment is retroactive to taxable years beginning after December 3I, 1938 , the objective test of worthlessness it applies may operate to take some debts out of Section I27 altogether. This is true where such debts had become uncollectible and worthless in fact prior to December 7, 1941, but had not been ascertained to be worthless and charged off on such date, since Section 127 does not apply if a deductible loss has been sustained prior to that date.

The amendment to Section $322(\mathrm{~b})(5)$ providing a special seven-year statute on claims for refund based on bad debt and worthless security items should be definitely beneficial in safeguarding rights of taxpayers having investment interests in enemy countries: There is nothing in Section 127 which warrants an inference that Section $322(b)(5)$ is not intended to apply to such items merely because they constitute war losses. Section 127 (a) (3) only makes inapplicable Sections 23(g)(2) and $23(\mathrm{k})(2)$, the provisions imposing capital loss limitations, to investment losses which are also war losses.

The basic yardstick for determining the amount of loss sustained with respect to property deemed to be destroyed or seized under Section 127 is, of course, the adjusted basis of such property. ${ }^{20}$ It would have been difficult to justify any other rule as a matter of policy, and the adjusted basis rule is also capable of convenient administration. There would be no more reason for allowing a deduction for unrealized (and untaxed) appreciation in the value of property in Germany than in the case of a building in the United States destroyed by flood or tornado. Section $\mathrm{I} 27(\mathrm{~b})(\mathrm{I})$, however, requires the amount of loss to be determined with regard to any recoveries with respect thereto in the taxable year but without regard to any possibility of recovering such property or interest or compensation therefor in the taxable year or subsequently, other than insurance or similar indemnity. This is a

\footnotetext{
${ }^{20}$ It should be noted that $\$ 127$ does not require any allocation of loss between depreciation in value prior to the date of the declaration of war and the loss of remaining value after that date. If no deductible loss has been realized on account of the property prior to Dec. 7, 194I, it may become a war loss under $\$ \mathrm{r}_{27}$ and, if so, will support a deduction in the full amount of its adjusted basis. It is fortunate Congress adhered to this policy, since any rule which was based upon an effort to make a refined determination of the extent to which the outbreak of war was the proximate cause of the Ioss would have been administratively impossible. Implicit in such a rule would have been the necessity of valuing each item of property as of Dec. 7, I94r. No argument is necessary to show that such a requirement would have largely nullified the benefits of $\$ 127$, and would have been of doubtful benefit
} 
fair rule and reflects the realistic doctrine of the White Dental Manufacturing Company decision. ${ }^{21}$

Section $127(b)(2)$ introduces a somewhat different, though sensible idea. It permits the taxpayer to decrease the amount of its war loss for deduction purposes by all obligations or liabilities of the taxpayer with respect to such property or interest discharged or satisfied out of the property or interest upon its destruction or seizure, if the Commissioner is satisfied that such liabilities are so discharged or satisfied that the taxpayer is unable to determine whether there is such discharge or satisfaction in fact. The taxpayer's choice or election must, in order to be effective, be made within such time and in such manner as may be prescribed by Treasury regulations. This provision permits a banking corporation, for instance, which has a branch in an enemy country, to offset deposit liabilities against deposit assets in computing the loss to be deducted in its return. It also allows a taxpayer to deduct from the basis of property in an enemy area, which is subject to a mortgage or lien in favor of an enemy national, the amount of such encumbrance, thereby deducting the loss on a net basis. The probability is, in such cases, that the enemy government will use the assets under its control, so far as necessary, to pay the claims of its own nationals. ${ }^{22}$

The provision is correlated, however, with Section $127(\mathrm{c})$, relating to inclusion of recoveries in gross income, so as to protect a taxpayer who fails to claim a full deduction on a gross basis in reliance upon an assumption, proved subsequently to be erroneous, that the offset liabilities will be satisfied or discharged out of the property, and who is subsequently held liable to discharge such liabilities out of other property. Such protection is afforded by a provision in Section $127(\mathrm{c})(2)$ that the amount of such obligations and liabilities erroneously treated as discharged or satisfied under Subsection (b) shall be considered for the purposes of Section 127 as a deduction which did not result in a tax reduction. Hence, to that extent the recovery of the property against which such liabilities were offset or compensation therefor would not result in realization of income or gain in the year or years of such recovery.

Section $127(\mathrm{c})$ is based upon the general principle that the recovery of property deemed to have been destroyed or seized or of compensation or indemnity therefor results in realization of gain not to exceed the fair market value of the property when recovered or the amount of such compensation or indemnity, but the amount of income realized shall not in general exceed the amount of war loss deductions in prior years which operated to reduce any income tax liability of the taxpayer in a prior year or years. This is the so-called tax benefit rule. As will appear, how-

to most taxpayers, since it is by no means certain that Dec. 7, r94I value, if determinable at all, would in the majority of cases have exceeded the adjusted basis of the assets.

${ }^{21}$ Stspra note 6.

${ }^{22}$ Reg. 103 , $\$ 19.127$ (b) -I contains detailed provisions relating to and illustrating the meaning and application of this subsection. Space does not permit a full analysis here. 
ever, there is one important departure in Subsection (c) from a strict adherence to the rule. The operation of the section can best be illustrated by a concrete example. Assume that corporation $X$ owned a plant in Germany, the adjusted basis of which, on the date war was declared; was $\$ 1,000,000$. It also owned stock in an Italian company, all of whose assets were in Italy, with an adjusted basis of $\$ 500,000$ and a fair market value of $\$ 75^{0,000}$ on the date of the declaration of war. Corporation $X$ claimed and was allowed a deduction of $\$ 1,500,000$ in its return for the taxable year I94x, such return showing a net loss of $\$ 500,000$. The corporation had losses on its returns for 1942 and 1943 , before any deduction of the net operating loss for I94I under Section I22. Let us further assume that in 1946, $X$ recovers its German plant intact, and that such plant has a fair market value in that year of $\$ 900,000$. $X$ realizes gain reportable in its 1946 return in the amount of $\$ 400,000$, representing the excess of the value of the recovery over the portion of the I94I deduction, i.e., $\$ 500,000$, from which $X$ derived no tax benefit. Furthermore, the gain so realized in 1946 is taxable as ordinary income.

Let us further assume that the taxpayer in its taxable year 1948 procures compensation of $\$ 650,000$ for the loss of its stock in the Italian company. The entire amount recovered in that year constitutes gain under Section $I 27(\mathrm{c})$. The gain to the extent of $\$ 600,000$ will be subject to tax as ordinary income at full rates. But the remaining increment of $\$ 50,000$ is treated as a gain upon involuntary conversion. Whether or not such gain is recognized will be governed by Section II2(f) of the Code. To the extent such gain is recognized, it will be subject to tax under the provisions of Section $\operatorname{II} 7(\mathrm{j})$.

The taxation of such an increment as a gain upon involuntary conversion will probably be one of the features of Section 127 which will be criticised on grounds of policy. The interests of the revenue would have been adequately protected by taxing as ordinary income the value of recoupments or recoveries only to the extent justified by the tax-benefit principle, with the basis of the recovered assets adjusted accordingly. On the other hand, the rule of Section 127 (c) is not easy to criticise on purely logical grounds. Section 127 as a whole is based upon the concept of treating war losses as losses due to destruction or seizure. Such losses are now classified by Section $\operatorname{Ir} 7(j)$ as losses due to involuntary conversion. Section ${ }_{22} 7(c)$ merely treats such loss or destruction as itself a closed transaction and works out the future tax consequences accordingly. From a practical point of view, the matter does not seem to be of great importance, since it does not now seem probable that the value of recoupments or recoveries in a great majority of instances will be sufficient to bring this rule into operation. The valuation of recoveries in kind may well produce many difficult problems, but these seem unavoidable, if the revenue is to be given a fair measure of protection. ${ }^{23}$

\footnotetext{
${ }^{23}$ Section ${ }_{127}$ (d) contains specific rules to govern the determination of the basis of recovered property, but space does not permit an analysis of this subsection in the present article.
} 
Section $127(e)$ is important and is of unusual interest because it introduces into the income tax law for the first time the concept of a deduction-strictly limited, it is true-based upon the partial worthlessness of stock. The need for such a limited allowance, however, is clear. In many cases, virtually all the operating assets of a foreign subsidiary may have been in enemy territory, but it might have had intangibles, such as bank accounts in friendly countries, or accounts receivable from non-enemy nationals, sufficient in amount to leave some increment of value in the subsidiary's stock or securities. Hence, Section 127 (a) (3) would not be applicable and would give no relief. Yet the loss of value in the stock or securities would in all probability be permanent, because of the catastrophic character of the subsidiary's loss. Filing a consolidated return would not help since foreign corporations cannot be included in a consolidation, and also in many of these cases the requisite $95 \%$ stock ownership would not be present, although a simple control test could be satisfied.

Section ${ }_{227}$ (e) meets this problem in a rather ingenious way. In the first place, it applies only if the taxpayer owns not less than $50 \%$ of each class of the stock of the subsidiary corporation. In the second place, assets of the corporation, the adjusted basis of which constitutes at least $75 \%$ of the adjusted basis of all the assets, must be property deemed to be destroyed or seized under Subsection 127 (a) (I) or (2), but in the determination of such percentage certain kinds of assets specified in Section $127(\mathrm{e})(2)(\mathrm{A})$ are excluded, such as bank deposits in friendly countries, accounts receivable from non-enemy nationals, and obligations issued or guaranteed by the United States. In other words, the assets included are chiefly the operating properties.

If these basic conditions are satisfied, and if within one year after such property is deemed to be destroyed or seized or within six months after the date of enactment of the 1942 Act, such subsidiary corporation is liquidated, then that portion of the loss on such liquidation which would be attributable to such destruction or seizure, as established to the satisfaction of the Commissioner, is deductible under Section $\mathrm{r}_{27}(\mathrm{a})(3)$. Such loss on liquidation is not limited to loss on capital stock but applies to other interests of the taxpayer in the corporation, such as bonds or other securities or open accounts. Losses under Section 127 (e) are not necessarily realized in the year war was declared or in the year the property passed under enemy control, but rather in the year the liquidation is consummated. This is the more reasonable interpretation of the statute and is the rule stated in the regulations. ${ }^{24}$ It is clear, however, that the capital stock of the subsidiary may become a loss under Section 127 (a) (3), while Section 127 (e) must be satisfied to get a war loss deduction on the bonds. This would be the case where the value of the assets not deemed to be destroyed or seized would, in the event of liquidation, be insufficient to yield anything for the stock, i.e., the stock has become worthless.

${ }^{24}$ See Reg. I03, \$19.127(e)-r. 
There is a good administrative reason for the requirement of a liquidation as a condition to relief under Section $127(\mathrm{e})$. The effect of liquidation is to vest ownership of the properties deemed to be seized or destroyed, or the right to recover the same or indemnity therefor, in the taxpayer and other shareholders. If such properties are later recovered in kind or compensation received, the Government is more likely to collect any tax resulting therefrom under Section 127 (c) (2) than if it were required to rely solely on Section $127(c)(3)$, which in certain cases treats restoration of the value of investments deemed to be seized or destroyed as a recovery. But a rigid enforcement of the liquidation requirement would have nullified the application of Section 127 (e) in many cases for the practical reason that a liquidation of a foreign subsidiary which is technically valid under the applicable foreign law is frequently impossible under war conditions. The Treasury has recognized these practical difficulties and has stated in the regulations that Section $127(\mathrm{e})$ will not be denied application because of technical flaws in the liquidation, if the taxpayer has in good faith complied as fully as possible with the requirements of the applicable laws and if the taxpayer executes a statement of its determination to treat such liquidation as valid for all purposes, including the treatment of any recoveries with respect to assets or right to assets distributed to it in a manner consistent with Section $I 7(c)$ and files any waivers of the statute of limitations which may be necessary in order to protect the Government should the taxpayer subsequently contend the liquidation was invalid. ${ }^{25}$

In conclusion, there can be little doubt that, despite any imperfections it may have, Section 127 and related provisions represented a reasonable and bona fide effort to treat the losses of foreign property and investments of American taxpayers, caused by the catastrophe of war, in a fair and equitable manner. There can be even less doubt that it will produce much fairer results in a vast majority of cases, with less uncertainty and litigation, than would have been possible under the preexisting law. ${ }^{28}$

\footnotetext{
${ }^{25}$ See Reg. 103, $\$ 19.127(e)-I(a)(3)$. This provision is a fair and practical one. Of more doubtful reasonableness, though probably technically valid, is a method of allocation prescribed by $\$ 19.127$ (e)-x(b), which operates to limit the war loss deduction to that part of the loss of value of the stock or securities which is in fact attributable to the particular assets, included in the computation of the percentage, which are deemed to have been destroyed or seized. Since the requisite percentage under $\$ 127(e)$ is so high, the complications in administration arising out of this formula seem to outweigh the benefit to the revenue of this refinement, however justified in theory it may be.

${ }^{20}$ The question may be asked whether $\$ 127$ is mandatory in the sense that the taxpayer must claim its benefits. Suppose a taxpayer has foreign property or investments but, because they all have a very low basis or because the taxpayer is confident of their recovery intact after the war, no deduction whatever for war losses is claimed on their account in the taxpayers returns. It is clear that \$127 does not treat their recovery in such a case as a transaction productive of income or gain on involuntary conversion. There has been no tax benefit whatever in' such a case, and $\$$ I27 does not operate automatically to reduce the basis of such property or investments to zero. Section $127(c)$ only functions if the taxpayer has taken some war loss deductions. But the taxpayer cannot pick and choose, i.e., claim deductions on items of property with a high basis and omit items wtih a low basis. If such an attempt is made, $\$ r_{27}$ will be applicable in the regular way to all recoveries, although the failure to include certain items in the war loss deduction may limit the amount of deduction resulting in a tax benefit.
} 